\title{
Financial Statements Analysis to Forecasting financial needs for Sports Clubs: Case Study of Al-Ahly Egyptian Club.
}

Raafat Said Hendawei

Administration and Recreation Department, Faculty of Physical Education for Boys, Alexandria Universit, Egypt.

Abdallah Mohamed Mohy El-Dien

Administration and Recreation Department, Faculty of Physical Education for Boys, Alexandria Universit, Egypt.

\begin{abstract}
The study aims to forecasting the financing needs of Al-Ahly Egyptian club through analysis of financial statements of the $C l u b$, represented in the list of the balance sheet financial analysis, statement of profits and losses, cash flow statement for the period from 2004 to 2012. As well as the preparation of a quantitative model to forecasting financial needs and the surplus cash for each resource of self-financial of the club. Descriptive approach was adopted to represent data and information on the study with a dependence on the analytical method in the interpretation of that information and draw conclusions from them. Empirical part of the research depends on the case study For the purpose of in-depth and detailed search of specific situation on the ground and apply the results of the theoretical study on the case namely study of Al-Ahly Egyptian club for the period from 2004 - 2012. The collection of required financial data depends on the documentary content of the report of the club's board for 9 years. The study model shows that the most influential variables in the prediction of financing needs and the cash surplus of Al-Ahli club namely, memeberships and annual fees revenue, miscellaneous income, revenues games, Ahly magazine revenues, Al-Ahram contract revenue, centenary revenue, social activity expenses, which is shown by the model predictive methods for multiple regression analysis
\end{abstract}

Keywords

Financial statement analysis, forecasting financial needs, self financial, financial resources, sports clubs, financial forecasting, financial revenues, multiple regression analysis.

\section{Introduction:}

$\mathrm{T}$ The concept of the financial of just a job specializes in the management of the financial resources needed to function competent to make decisions in the investment and finance field in which these decisions affect the enterprise value and ways to maximize this value, which is affected by many variables as the expected incomes or profit, risk and time dimension and its impact on cash flow (16: 8) (18:17)

Decision-making is the essence of administrative practice in order to solve the daily problems facing the administration, this decision is not by random or chance, but requires the use of quantitative techniques in order to be a sound decision, and from these techniques we find forecasting techniques. (10:13)

The Forecasting is a key component in determining the future operations, problems and opportunities and is an essential part of the efficient and effective management as a critical modeling tool for decision-making and then the prediction of commitment has grown steadily in the recent period for all types of organizations. (21:41)
Quantitative or qualitative methods or a combination of both can be used for taking prediction. Qualitative methods used in the prediction is more intuitive terms as it is based on the types of information represented in the judgmental, consensus and experts. While quantitative methods including other types of information as a trend analysis, multiple regression analysis, and time series analysis.(26)

This the process of assessing the financial needs and identifying appropriate resources of financial are based on financial forecasting, which is in turn of the fundamental responsibility of the Financial director where he provides the project with framework based on planning and control of project operations financial forecasting were divided to the short-term financial forecasting, the long-term financial forecasting, therefore forecasting methods differs according to the time period, the more famous long-term forecasting methods is the regression with its various types represented in simple regression, multiple regression, linear or non- linear regression terms of choice based on the type of regression, according to the number of variables. (14: 91) 


\section{Problem of the Study}

Sport is a very sophisticated system and often is complex in many respects, especially in the legal and financial aspects as a form of business where consumers are the fans and the players, and the producers are clubs and associations and linkages and periodicals. The sports arenas and stadiums are distribution channels for these products. (24)

Financial statements are used for the characterization of the results of the financial operations of the club, should be taken into considered the data contained in the financial statements as it is the performance cards of the club when it is compared with the operations budget for the same accounting period, by this way you can determine the degree of financial success for the club, as well to predict the amendment future expectations based on the actual performance and preparation of updated expectations lists. And could include adjustments to the budget, Forecasting, re-forecasting, or "rolling-forecasting " can be conducted several times during the budget period, and can be extended from one financial period to the next. (23)

The sports institutions suffers from financial crises due to the increase of expenses over revenues, which represents a major obstacle for the progress of sports levels ,the sport domains has become a burden on the country resources, in view of increasing in number of the sports institutions and increasing its requirements these make the country suffers from achieving sufficiently to these sporting institutions, but were supported in the available limits and become sufficient for the fundamental requirements to achieve success of those institutions ,there is a decrease in the rate of financial contributions or difficulty in its availability and validity and decline of financial resources (6: 79.80,. 99)

This is confirmed by the results of Crystal Apilad study (2003) (20) "the funding challenges for sporting clubs." The support for clubs and sports organizations is very small, the trend towards reducing expenses, Support the voluntary systems to meet the needs of sports activities, Lack of support leads to negative aspects especially which in link with some participants in sports teams, directing government financial towards community care services, particularly for children and education and health systems.

The results of Khaled Abd Elatty study (2000) (5) that the Egyptian sporting clubs have found a solution for the problem of the lack of the governmental supports and the decline of money. Tracking with the global clubs, as a search to find self-financing resources through investment facilities or activities, as raise revenue from annual contributions of members, membership fees, sell tickets for games or concerts held by the organization, rent their facilities, the deposits of financial proceeds.

This is consistent with the results of Abdullah Mohiuddin study (2007) (9) that sporting clubs can increase their financial resources through a group of marketing activities such as (Sports sponsor, Intellectual property of the club brand, Broadcast right for local and international matches, Matchday revenues, Advertisements on the players shirt, Advertisements on the wall of the club, Advertisements around the stadium and players seating places, Marketing through the club website, Establishment journal for the club, set up a TV channel)

Here determined the problem of this research as most sports clubs do not gauge the effectiveness of the resources of self-financing, most officials are unaware of the importance of the evaluation process, which can contribute to identify the resources of the most effective financial and work on its development. The resources of less financial effectiveness and knowledge of weaknesses for the development and improvement, Rating based on those resulting from the operation of the Consolidated Financial club, represented in the balance sheet of financial analysis of financial information (balance sheet), the statement of revenues and expenses, the cash flow statement. The financial statements are the most important types of accounting reports, which explains the success or failure of the enterprise in the management of the available resources, as it represents the primary source of financial information for interested parties to financial juncture club.

In addition the administrative decisions in the field of finance or investment is no longer an easy process, the decision-makers take it according to their own experience, this means did not taking any administrative decision only after an in-depth study and digital analysis for the closing financial statements, so the financial director can of the discover the power points and exploit it the best exploitation and identify weaknesses points to take the necessary corrective actions.

The study built their point of view on most of Egyptian sports clubs suffice with issuing an annual booklet issued by the club's board has a financial report for the club's budget and the annual draft budget during the general assembly, not only that but had shortcut all details of this report to one number only be conference in all media ,which is the total revenue of the club, Unwiring the value of the financial information implemented in the financial statements of the club if it taken over a continuous period 
of time in finding a quantitative model can be relied on to forecasting financial needs and identify the more financial resources influential in the cash surplus for the club as well as exclusion the least influential resources in the cash surplus.

So this the study is trying to identify the effectiveness of the self-financing resources for sporting clubs through its impact on the financial position and the clubs profitability and thus predict future financial needs and previous prepare for them and take the corrective action if there is a necessary.

\section{Previous studies}

1- Halima Khalil El Gergawy (2008)(3) "The role of the financial analysis for the financial information published in the financial statements to Forecast the prices of equities." The study aimed to identify the dimensions of financial analysis, its advantages and how to take advantage of it in forecasting the equities prices by testing a range of financial ratios and create a quantitative model that can be relied on to predict the price of the equities for each sector of the Palestine Exchange sectors, so as to help investors to take informed decisions during the investment process. Has been reached several quantitative models for each sector of market sector (the insurance sector, banking sector, investment sector, the services sector, the industrial sector), The study concluded that can rely on a set of financial ratios for each sector of these sectors to Forecast the price of the equities, the study recommended increasing the attention to the financial statements, prepare it transparency in disclosure its data and prepare it according to international accounting standards, and the investor can rely on the financial analysis of the financial statements during taking the investment decisions

2- Musa bin Mansour (2010)(17) " The Role of Financial Analysis in the rationalization of mongering between the companies decision " The study aimed to identify highlight the role of the financial analysis in the rationalization of merging between the companies through clarifying how to estimate the value of the companies involved in this merge and how to resolve the value of the deal the researcher had identified that the merging decision between companies is investment decision as to buy a company for a company or union with it or control it Means investment for the company and its implementation would require the application of the same basic principles for any investment decision, especially with regard to the profit yield and cost Moreover, purchasing a new company means taking into considered the company purchased decision and the result of his decision. on this basis, the mongering decision requires the integration, accuracy and caution and here appear are the leading role of financial analysis where it works to rationalize the merging decision through contributing in the most difficult step is the evaluation process which is the evaluation process and how determine the repay value of the deal.

3- Sahry Gamal Abdel Nasser (2012)(7) " The financial analysis as a tool for making decision in the petroleum enterprises in Algeria , study the case of ENSP institution (2010, 2011,2012)" The aim of the study was to determine and indicate the role of financial analysis in managerial and Financial decision-making in petroleum enterprises in Algeria, the study concluded a set of results the most important is that the analysis is an effective and rationalization tool for decision-making because it helps the financial manager to diagnose the financial situation of the institution and disclosure its policy and circumstances , also helps to know the weaknesses points to avoid them and strengths points to promote and evaluate then, so the financial manager must accurate and comprehensive understand the mysteries of financial analysis and control its mechanisms, and understand of the basics of the resolution (steps, methods).

4. Dianne Waddell, Amrik S. Sohal (1994)(21) " Forecasting: The key to managerial decision making", The most important results is the good Forecasting is an essential part of the efficient and effective management as they are modeling critical tool to take both the strategic and tactical decision, Therefore must abide the forecasting in all kinds of organizations. One of the most important results also is the absence of perfect forecasting method works under all circumstances. Even when the administration find a patients approach should continue to monitor and control other forecasting to be sure the errors are under control in addition to that Forecasting can often be a very difficult part, but is the important part for management

5. Sumewar Kesh, M.K. Raja (2005) (28) " Development of a qualitative reasoning model for financial forecasting" aims to clarify how to develop the qualitative conclusion models in the financial field, and the applicability of these models, problems and issues related to development the inference qualitative models in the field of financial resources, the study results showed that the qualitative conclusion models can be used to predict the financial branch, control and decision-making processes, it is possible to develop and use the more complex models for specific applications in various business areas. Since making decision in commercial branch required quantitative and qualitative inputs, it becomes like those of great practical value models. 
6. Sergei Vasilievich (2008)(27) " Long-term financial statements forecasting: reinvesting retained earning " aims to compare the predictions based on invested capital and predictions based on revenues, which greatly vary with retained profits treatment and indicate the differences in balancing sheets. The most important results was the forecasting entrance of the totaling long-term assets and property and equipment compared to the forecasting entrance of the net long-term assets and property and equipment which is more convenient and the study suggested achieve the balance between the financial statements in accordance with the interest expenses on the basis of the average debt at the beginning and end of the year and perform this procedure by putting intermediate tables for the cash calculation and debt accounts.

7. Erik Hofmann, Kerstin Lampe(2012)(22) " Financial statement analysis of logistics service providers, ways of enhancing performance" aims to restructure the balance sheets, according to logistics service providers in order to see if there were differences between the individual providers or the identified logistics providers groups, moreover, it was referring to the adoption of assets, capital and liquidity structures on the specific characteristics of the logistics service providers, to clarify any financial indicators with a positive impact on the profit the most important findings that there are many variations on the financial infrastructure for logistics service providers. The structural liquidity and asset logistics service providers are showing large variations in the head while the homogeneous capital structure mostly. Achieve profitability in different ways: Focus on the high net profit margin or assets turnover rates.

8. Steven Isberg, Dennis Pitta (2013)(29) " Using financial analysis to assess brand equity " aims to explain how to assessment brand equity through analysis using the available financial statements for public to assess brand equity, were the most important findings is that measuring brand equity has become an elusive goal for production managers. The quality of tariffs is available, while a few studies attempted to determine the brand equity of a company or product. Focus the techniques of the financial analysis on equity return and property return, while this study searches two strategies for development by distinctive trademarks. The first is development by acquisitions, and the second is development by basic brand.

\section{The study terms}

Financial Statement Analysis: a structured process to treat the available financial data of a institution to obtain information used in the decision-making process and evaluate the performance of institution in the past and predict what the situation will be in the future through the collection and correction of the financial statements and briefly submit them suit to the financial making decision or operational process $(19: 7)$

Forecasting financial needs: it is a financial planning supports the purpose of determining the financing needs of the future and securing the necessary funds in a balanced manner of different financial resources. (12:59)

\section{Objectives of the study}

Forecasting financial needs for Al-Ahly Egyptian club through: -

- Financial Analysis for the club financial statements, represented in the balance statement, revenues and expenses statement, cash flows statement for the period between 2004 until 2012.

- Prepare a quantitative model to forecasting the financial needs and the surplus cash for each source of self-financial resources for Al-Ahly Egyptian club.

\section{Questions of the study}

- What is the contribution percentage of revenue and expenses in the forecasting of financial needs of selffinancial resources for Al-Ahli Egyptian club?

- What is the contribution percentage of revenues and expenses in determining the surplus cash for each selffinancial resource for Al-Ahly Egyptian club?

\section{Procedures}

Methodology: These study used the descriptive approach in the presentation of concepts, data and information of the study, depending on the analytical approach in the interpretation of that information and draw conclusions from them, that in the theoretical side, but in the applied side both of researchers relied on the approach of studying the case for the purpose of deep and detailed search for the specific situation and apply the results of the theoretical study on it in the case of for Al-Ahly Egyptian club in the period between 2004 - 2012.

Sample: The study was applied in Al-Ahli Egyptian club, which the financial statements are available through time series between 2004 until the end of 2012. The study variables were identified as potential availability According to figures and financial statements that have been disclosed and included clearly in the published financial statements which are shown in Figure (1). In addition to the competitive position of the club in various sports and its relation to the search for new and effective 
financial resources, as it is the first club which have a marketing and investment management having a specific organization structure for a long period of time. Al-Ahly Sporting club was established in April 1907 as a social sports club and announced by the Youth Welfare under No. 1124 dated 1959 and then re- announced in accordance of Law No. 77 of 1975 of Youth and Sports Welfare No. 52 dated February 7, 1976 with the aim of formation youth character in social, health, psychological and intellectual aspects. Al-Ahly Club in the preparation of the annual financial statements and annual quarter depends on historical cost basis in accordance with the decision of the Minister of Youth No. 1173 of 2000 , the Egyptian laws and accounting standards with respect to the currency measurement- Translation transactions by foreign currency- Fixed Assets - demonstration and assessment of financial investments - stock - Catch, owe sheets and other debit balances - appropriations - Proof of income and expenses - Social Security - cash flows. So financial statements fairly and clarity expresses the club's financial position and financial performance and its cash flows. (1: 63)

Data collection tools: study in financial data collection depends on analysis the content of the club's management report about the budget and the draft budget for Al-Ahli Egyptian Club for the nine financial years beginning from 2004 and until 2012.

Statically treatments: the study use some statically treatments as (Percentage-correlation -Average - multiple regression analysis) and had used the statically program SPSS For the statically treatment for the research information.

Figure (1) revenue and expenses resources of Al-Ahly Egyptian club

\begin{tabular}{|c|c|c|c|}
\hline Memberships \& annual fees & Miscellaneous income & Units revenues & Social activity revenues \\
\hline $\begin{array}{l}\text { - Structural subsidy } \\
\text { - Annual subscriptions } \\
\text { - Replacement and renewal } \\
\text { fees } \\
\text { - Membership card fees } \\
\text { - Marina Subscription } \\
\text { - Registration fees } \\
\text { - Use tires fees } \\
\text { - Re-registration fees }\end{array}$ & $\begin{array}{l}\text { - Donations and gifts } \\
\text { - Shows } \\
\text { - Rents } \\
\text { - Visits ticket } \\
\text { - Delay penalties } \\
\text { - Member ship requests } \\
\text { - Sale store remnants } \\
\text { - Advertising } \\
\text { - Net café } \\
\text { - Nasr city library } \\
\text { - Tender } \\
\text { - General organization fines }\end{array}$ & $\begin{array}{l}\text { - Swimming pool } \\
\text { - Physical therapy treatment } \\
\text { - Telephones } \\
\text { - Medical clinic } \\
\text { - Covered hall }\end{array}$ & $\begin{array}{l}\text { - Trips } \\
\text { - Camps } \\
\text { - Summer resort } \\
\text { - Billiards } \\
\text { - Bridge }\end{array}$ \\
\hline Games revenues & Al-Ahly magazine revenues & Ahram contract revenues & Centenary revenues \\
\hline $\begin{array}{l}\text { - Soccer } \\
\text { - Anather games } \\
\text { - The academic } \\
\text { - The African champion } \\
\text { - The Arabian champion }\end{array}$ & $\begin{array}{l}\text { - Local distribution } \\
\text { - Overseas distribution } \\
\text { - Advertisements } \\
\text { - Subscriptions } \\
\text { - Sale of returns }\end{array}$ & $\begin{array}{l}\text { According to the contract } \\
\text { with the club in } 23 \text { October } \\
2008 \text { for three seasons ends } \\
\text { in } 2010 / 2011\end{array}$ & $\begin{array}{l}\text { Financial values collected from } \\
\text { the celebration sponsers } 2007 \text { - } \\
2008\end{array}$ \\
\hline
\end{tabular}




\begin{tabular}{|c|c|c|c|}
\hline Administrativ expenses & Al-Ahly magazine expenses & Social activity expenses & Games expenses \\
\hline $\begin{array}{l}\text { - Salaries and bonuses } \\
\text { - Public Expenses } \\
\text { - Water and lighting } \\
\text { - Maintenance and repairs } \\
\text { - Printing member ship cards } \\
\text { - Writing tools } \\
\text { - Maintenance play grounds } \\
\text { - Computer Expenses } \\
\text { - Nasr city library Expenses }\end{array}$ & $\begin{array}{l}\text { - Administrative Expenses } \\
\text { - Printing Expenses } \\
\text { - Instead of transmission for } \\
\text { the editing staff } \\
\text { - Instead of transmission for } \\
\text { the coaching staff } \\
\text { - Instead of transmission for } \\
\text { the administrative staff } \\
\text { - Writing tools }\end{array}$ & $\begin{array}{l}\quad \text { Unit expenses } \\
\text { - Swimming pool } \\
\text { - Physical therapy treatment } \\
\text { - Telephones } \\
\text { - Medical clinic } \\
\text { - The covered hall }\end{array}$ & $\begin{array}{l}\quad \text { Centenary expenses } \\
\text { - General Expenses } \\
\text { - World hand ball champion } \\
\text { - Centenary caravans } \\
\text { - Barcelona and Benfica match } \\
\text { - Transmission and transfer } \\
\text { Expenses } \\
\text { - Bonuses }\end{array}$ \\
\hline Results & & & \\
\hline
\end{tabular}

First: Al-Ahli club revenue from 2004 to 2012

Table (1) Statistical description of Al-Ahly club revenue for the period from 2004 to 2012.n=9

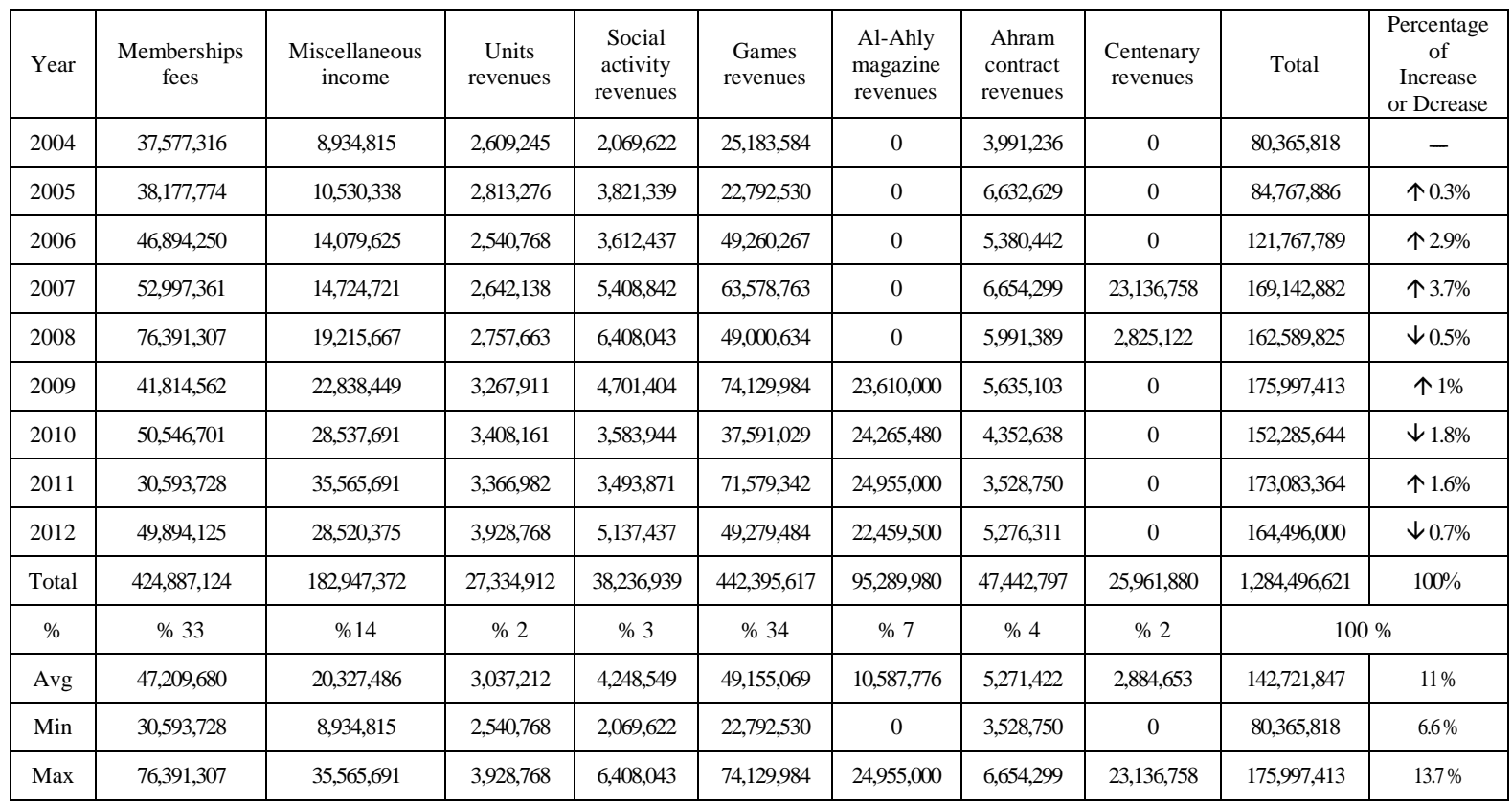




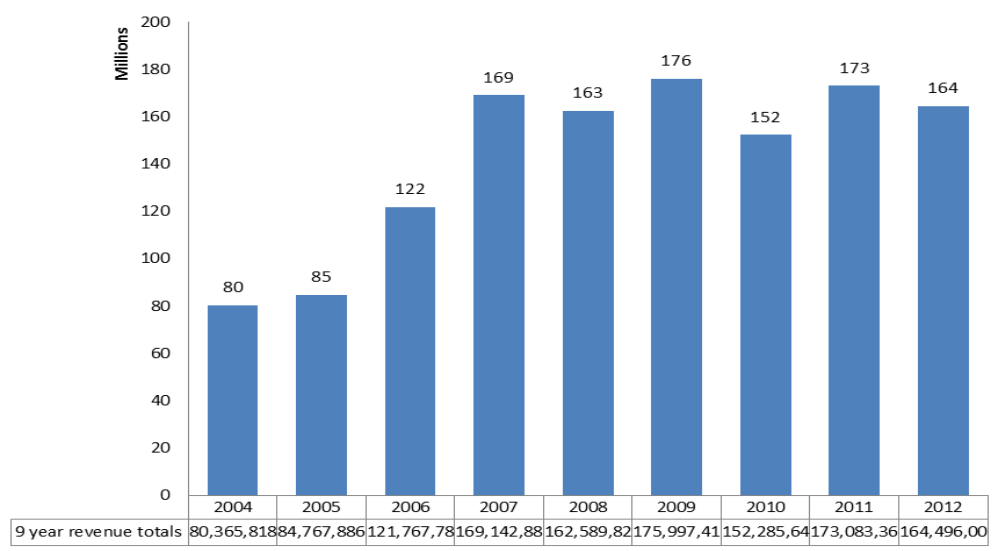

As Shown in Table 1 and Figure (1) that the total actual income of Al-Ahli club during the period from 2004 to 2012 amounted L.E. 1,284,496,621, When the financial values of revenues ranged between (L.E. 80,365,818) in 2004, which is $6.3 \%$ of the total revenue, to (L.E. 175997 413 ) in 2009 , which is $13.7 \%$ of the total actual income of the club. Reveals an upward increase in revenue in the period from 2004 until 2007, the club achieved an increase in revenue by $0.3 \%$ in 2005 and $2.9 \%$ in 2006 and finally $3.7 \%$ in 2007. Considering the period from 2008 to 2012 when the club achieved its greatest revenue despite the rise and fall of financial values in 2008, the club realized revenue of 162589825 L.E., with a decline of $0.5 \%$ from the previous year. Also Al-Ahli club in 2009 earned revenue of L.E. 175997 413, with increase of 1\% from the previous year, considered to be the highest value of revenue achieved by Al-Ahly Club during the period from 2004 until 2012.

In 2010, the actual revenue of Al-Ahli club had reached L.E. 152285 644, a decline from the previous year of $1.8 \%$. Then the club achieved an increase in revenues during 2011, when actual revenues amounted 173083364 with $1.6 \%$ a rate of increase. Then revenues of the club declined in 2012 from the previous year where the club has achieved actual revenue amounted to L.E. 164.496 million, a downturn of $0.7 \%$ from the previous year

The results of the analysis of the financial statements of the club have shown a variation in the percentage contribution of each fiscal year in the total aforementioned revenues over the 9-year. Ahly gained the highest annual revenues in 2009 amounted 175997413 L.E. with a contribution rate of $13.7 \%$ of total revenues, which makes it ranks first among the rest of the fiscal years. While 2011 comes to be the second, revenues amounted L.E. 173083 $364,13.5 \%$ of total revenues. 2007 comes to be the third, with revenues amounted 169142882 L.E, 13.2\% of total revenues. The last place is 2004 with revenues of L.E. $80,365,818,6.3 \%$ of total revenues

Then the study will review in more detail resources of revenues of Al-Ahly club, the weight of each source , and its power to the change of financial values with increase or decrease over the period from 2004 to 2012, which are shown in Figure (2) (3)

Figure (2) the financial values of total revenues of financial resources over 9 years

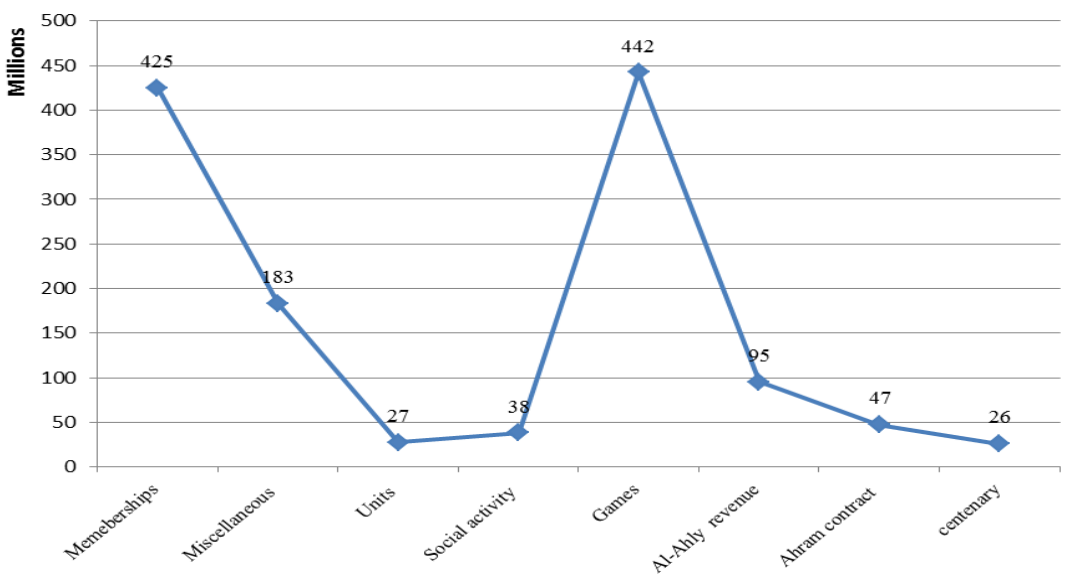


Figure (3) Relative Distribution to total revenues of financial resources over 9 years

\author{
- Memeberships \& fess revenue \\ - Miscellaneous revenue \\ - Units revenue \\ n Social activity revenue \\ - Games revenue \\ a Al-Ahly magazine revenue \\ Ahram contract revenue \\ a centenary revenue
}

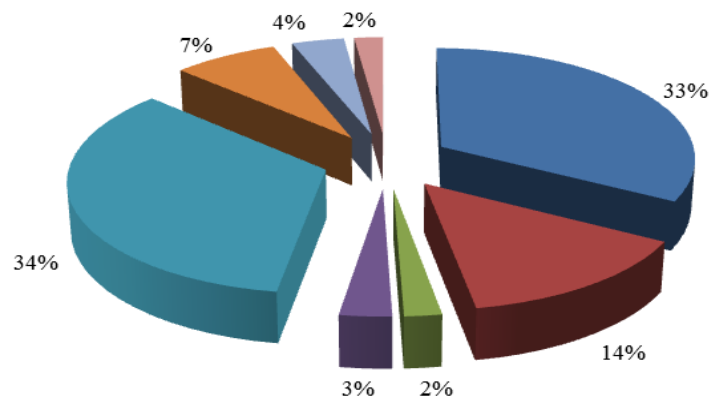

It is clear from Figures (2) and (3) that there is a variation in the financial values of revenues for Al-Ahli club over the 9-year period from 2004 to 2012 from various resources of financial, like the memerships and annual fees, miscellaneous incomes, revenue units, revenues of social activities, revenues of athletic, Ahram's contract revenues, Al-Ahly magazine revenues, revenues from Centennial celebrations

Each of these resources has varied contribution to the total earned revenue of 1,284,496,621 LE. The results show that the total revenues of the Al-Ahly from athletics reached L.E. 442395617 with yearly average of L.E. $49,155,069,34 \%$ of total revenues and the largest source of income. While revenues from memerships and annual fees considered to be the second, reaching L.E. 424887 124 L.E. with yearly average of L.E 47.20968 million, $33 \%$ to total revenues

Miscellaneous incomes is in third place, reaching an L.E. 182947372 L.E. with yearly average of 20,327,486, $14 \%$ to total revenues.

\section{Second: Al-Ahly Club expenses from 2004 to 2012}

Shown in Table 2 and Figure (4) that the total expenses of Ahly club during the period from 2004 to 2012 amounted L.E. 953983196 where values of financial expenses ranged between (L.E. 58,852,019) in 2004, 6.2\% of total expenses to (L.E. 170.975 million) in 2012 with an increase by $17.9 \%$ of the total expenses of the club for the same time period. The results of the analysis of the financial statements of the club show variation in the percentage contribution of each fiscal year over the 9-year to total expenditures. The expenses of the club in 2012 was 170975000 L.E., representing \% 17.9 of the total expenses and an increase of $6.8 \%$ copmpared to thd former year, which makes it ranks first among the rest of the fiscal years .while fiscal year 2009 comes in the second place with expenditures of L.E. 128037 273, representing $13.4 \%$ of the total expenses and with an increase of $2.4 \%$ in expenses compared to 2008. While fiscal year 2007 comes to be the third, with total expenses of 123613339 L.E. ,representing $13 \%$ of total expenses and an increase of $3.9 \%$ in expenses compared to 2006 .The last place is in 2004, where expenditures was L.E. $58,852,019$ with an increase of $6.2 \%$ of total expenses.

Table (2) Statistical description of Al-Ahly club expenses for the period from 2004 to 2012.n= 9

\begin{tabular}{|c|c|c|c|c|c|c|c|c|}
\hline Years & $\begin{array}{l}\text { Administrativ } \\
\text { expenses }\end{array}$ & $\begin{array}{c}\text { Unit } \\
\text { expenses }\end{array}$ & $\begin{array}{c}\text { Social } \\
\text { activity } \\
\text { expenses }\end{array}$ & $\begin{array}{c}\text { Games } \\
\text { expenses }\end{array}$ & $\begin{array}{c}\text { Ahly } \\
\text { magazine } \\
\text { expenses }\end{array}$ & $\begin{array}{l}\text { Centenary } \\
\text { expenses }\end{array}$ & Total & $\begin{array}{c}\text { Percentage } \\
\text { of } \\
\text { Increase } \\
\text { or Dcrease }\end{array}$ \\
\hline 2005 & $20,458,156$ & 860,732 & $3,851,882$ & $38,588,901$ & $3,658,207$ & 0 & $67,417,878$ & $\uparrow 0.9 \%$ \\
\hline 2006 & $25,120,578$ & 786,809 & $3,145,098$ & $54,323,950$ & $3,323,565$ & 0 & $86,700,000$ & $\uparrow 2 \%$ \\
\hline 2007 & $28,771,717$ & 712,155 & $5,365,869$ & $67,856,883$ & $4,430,807$ & $16,475,908$ & $123,613,339$ & $\uparrow 3.9 \%$ \\
\hline 2008 & $30,058,011$ & 717,971 & $6,110,323$ & $61,172,358$ & $4,005,830$ & $2,860,660$ & $104,925,153$ & $\downarrow 2 \%$ \\
\hline 2009 & $36,467,363$ & 799,566 & $4,608,775$ & $82,186,716$ & $3,974,853$ & 0 & $128,037,273$ & $\uparrow 2.4 \%$ \\
\hline 2010 & $37,424,535$ & 717,790 & $3,634,060$ & $62,702,787$ & $2,811,295$ & 0 & $107,290,467$ & $\downarrow 2.2 \%$ \\
\hline 2011 & $32,858,344$ & 674,803 & $3,184,067$ & $67,152,028$ & $2,302,825$ & 0 & $106,172,067$ & $\downarrow 0.1 \%$ \\
\hline
\end{tabular}




\begin{tabular}{|c|c|c|c|c|c|c|c|c|}
\hline Years & $\begin{array}{c}\text { Administrativ } \\
\text { expenses }\end{array}$ & $\begin{array}{c}\text { Unit } \\
\text { expenses }\end{array}$ & $\begin{array}{c}\text { Social } \\
\text { activity } \\
\text { expenses }\end{array}$ & $\begin{array}{c}\text { Games } \\
\text { expenses }\end{array}$ & $\begin{array}{c}\text { Ahly } \\
\text { magazine } \\
\text { expenses }\end{array}$ & $\begin{array}{c}\text { Centenary } \\
\text { expenses }\end{array}$ & $\begin{array}{c}\text { Percentage } \\
\text { of } \\
\text { Increase } \\
\text { or Dcrease }\end{array}$ \\
\hline Total & $285,893,079$ & $7,581,285$ & $39,251,183$ & $568,345,400$ & $33,575,681$ & $19,336,568$ & $953,983,196$ & $100 \%$ \\
\hline$\%$ & $30 \%$ & $1 \%$ & $4 \%$ & $59 \%$ & $4 \%$ & $2 \%$ & \multicolumn{2}{|c|}{$100 \%$} \\
\hline Avg & $31,765,898$ & 842,365 & $4,361,243$ & $63,149,489$ & $3,730,631$ & $2,148,508$ & $190,796,639$ & $20 \%$ \\
\hline Min & $17,868,922$ & 674,803 & $2,260,711$ & $35,607,977$ & $2,089,759$ & 0 & $58,502,172$ & $6.2 \%$ \\
\hline Max & $56,865,453$ & $1,286,809$ & $7,090,398$ & $98,753,800$ & $6,978,540$ & $16,475,908$ & $187,450,908$ & $17.9 \%$ \\
\hline
\end{tabular}

Figure (4) total expenses of Ahly club over the 9 yrears

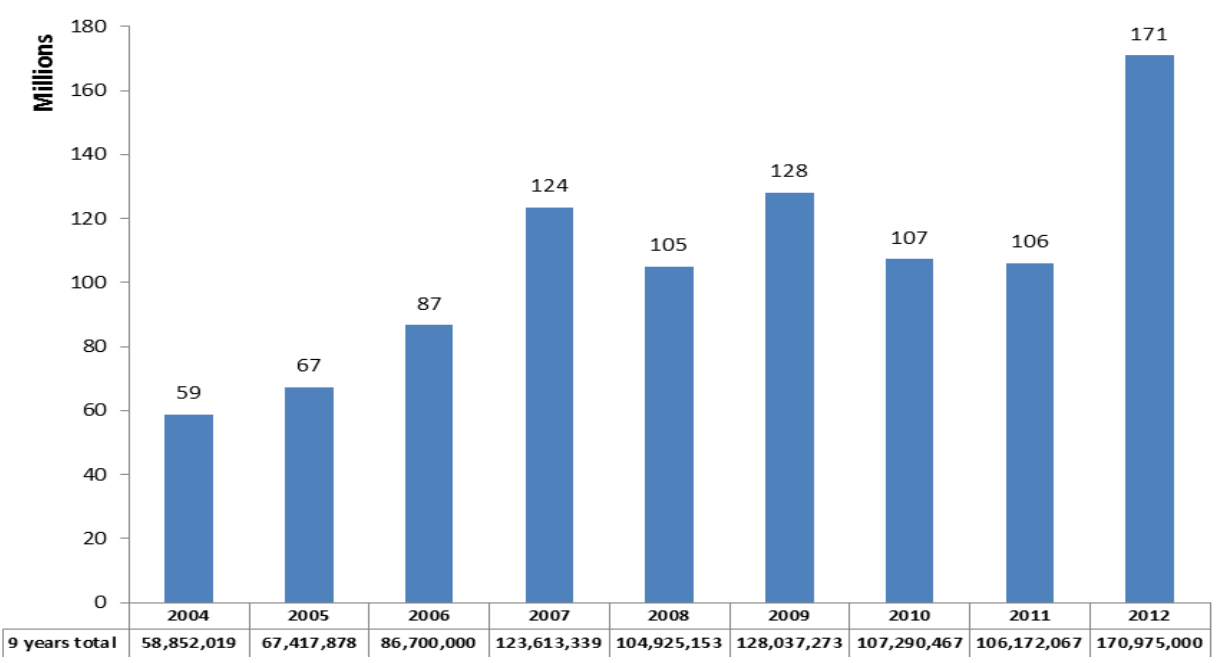

Then the study will review in more detail resources of expenditure of Al-Ahli club, weithght of each resources,its power to the chang values values of the expenditures, whether an increase or decrease over the period from 2004 to 2012, which are shown in Figures (4)(5)

Figure (5) the financial values of the Ahli club total expenditures over the 9 yrears

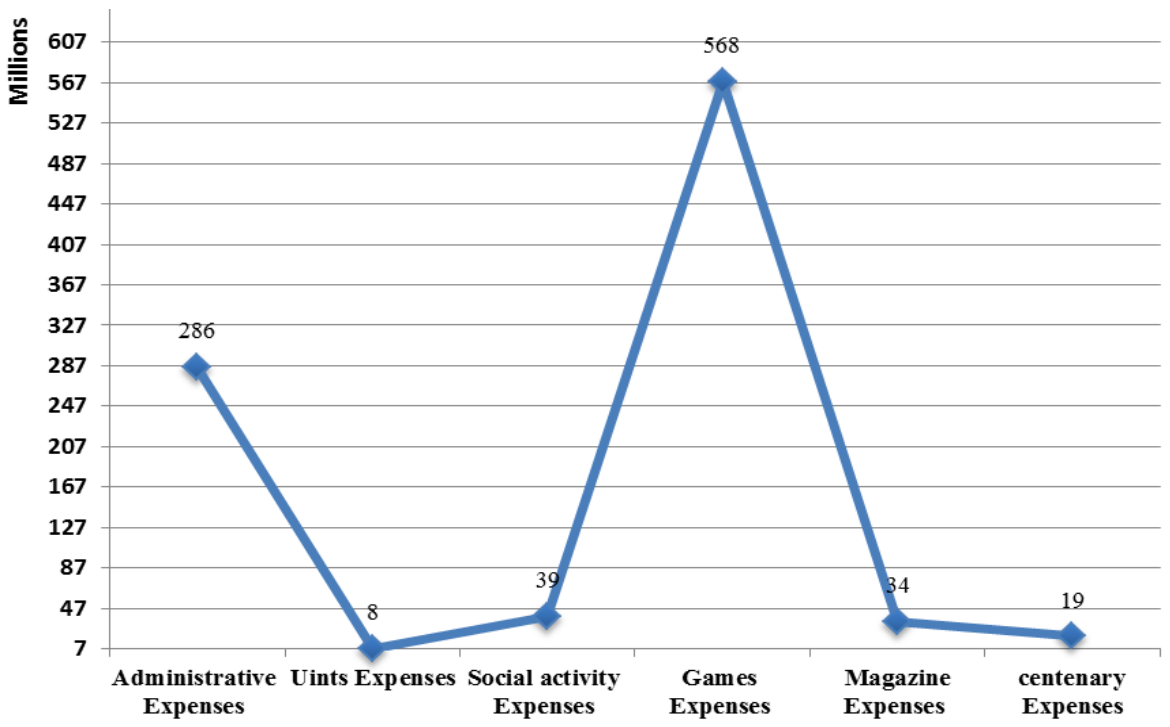




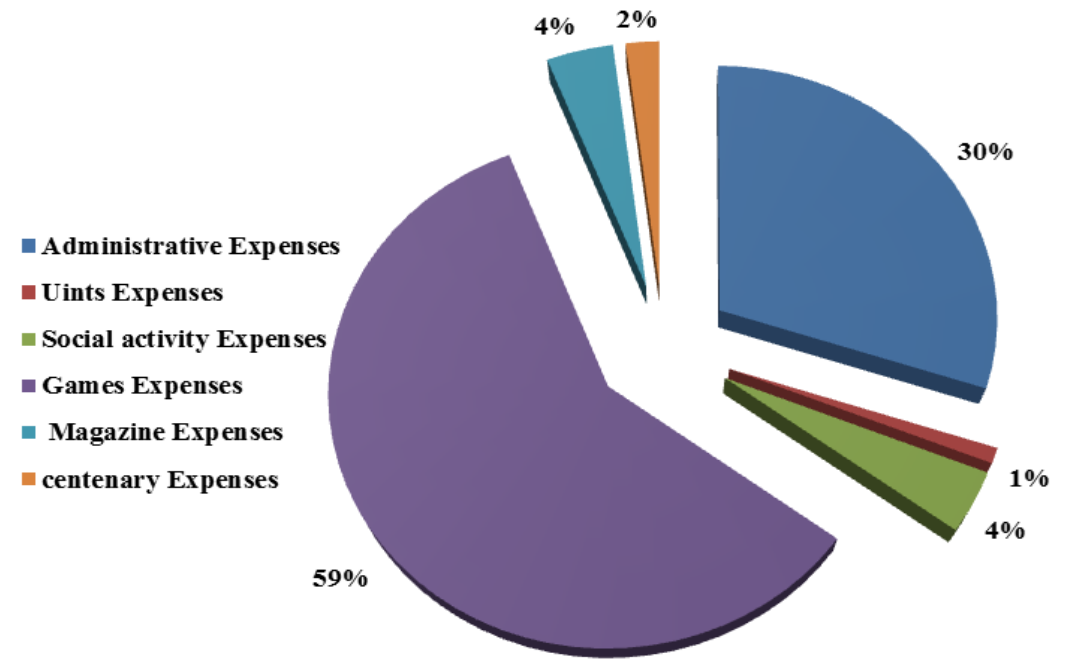

Figure (6) percenteg of the Ahli club total expenditures over the 9 yrears

Figures (4) (5) show variation in the financial values of the expenses of Al-Ahli club over 9-years period from 2004 to 2012 to various club activities represented in general and administrative expenses activities, units expenses, social activities expenses, games expenses, Al-Ahli Magazine expenses, centennial celebration expenses. Each of these activities has varied contribution to total expense which amounted LE 953983 196. The results show that the total athletics expenses amounted 568345400 with an average of L.E. $63,149,489$ per year, representing $\% 59$ of total expenses and makes it in the first rank. general and administrative Expenditure amounted 285893079 with an average of $31,765,898$ per year, representing $30 \%$ of the total expenditure , and makes it in the second rank.while the unit expense ratios, social activities expenses, Al-Ahly magazine expenses, centenary expenses is $1 \%, 0.4 \%, 0.4 \%$ , $0.2 \%$ respectively, which are weak ratios compared to others.

\section{Third: Financial Surplus of Ahli Club from 2004 to 2012}

Table (3) financial values of the surplus or deficit of cash after depreciation from 2004 to 2012.n=9

\begin{tabular}{|c|c|c|c|c|c|}
\hline year & Total Revenues & Total Expenses & Total surplus & Depreciation & $\begin{array}{c}\text { surplus or deficit after } \\
\text { depreciation }\end{array}$ \\
\hline 2004 & $80,365,818$ & $58,852,020$ & $21,513,798$ & $18,501,321$ & $3,012,477$ \\
\hline 2005 & $84,767,887$ & $67,417,878$ & $17,350,009$ & $13,763,450$ & $3,586,559$ \\
\hline 2006 & $121,767,789$ & $87,000,000$ & $34,767,789$ & $13,181,230$ & $21,586,559$ \\
\hline 2007 & $169,142,883$ & $123,613,338$ & $45,529,545$ & $34,669,210$ & $10,860,335$ \\
\hline 2008 & $162,589,825$ & $104,925,152$ & $57,664,673$ & $52,731,949$ & $4,932,724$ \\
\hline 2009 & $175,997,413$ & $128,037,273$ & $47,960,140$ & $46,188,568$ & $1,771,572$ \\
\hline 2010 & $152,285,644$ & $107,290,468$ & $44,995,176$ & $58,261,076$ & $-13,265,901$ \\
\hline 2011 & $173,083,664$ & $106,172,067$ & $66,911,597$ & $96,121,911$ & $-29,210,615$ \\
\hline 2012 & $164,496,000$ & $170,975,000$ & $-6,479,000$ & $33,279,000$ & $-39,758,000$ \\
\hline Total & $1,284,496,923$ & $954,283,196$ & $330,213,727$ & $366,697,715$ & $-36,484,290$ \\
\hline Average & $142,721,880$ & $106,031,466$ & $36,690,414$ & $40,744,191$ & $-14,620,775$ \\
\hline Min & $80,365,818$ & $58,852,020$ & $-6,479,000$ & $13,181,230$ & $-39,758,000$ \\
\hline Max & $175,997,413$ & $170,975,000$ & $66,911,597$ & $96,121,911$ & $21,586,559$ \\
\hline
\end{tabular}




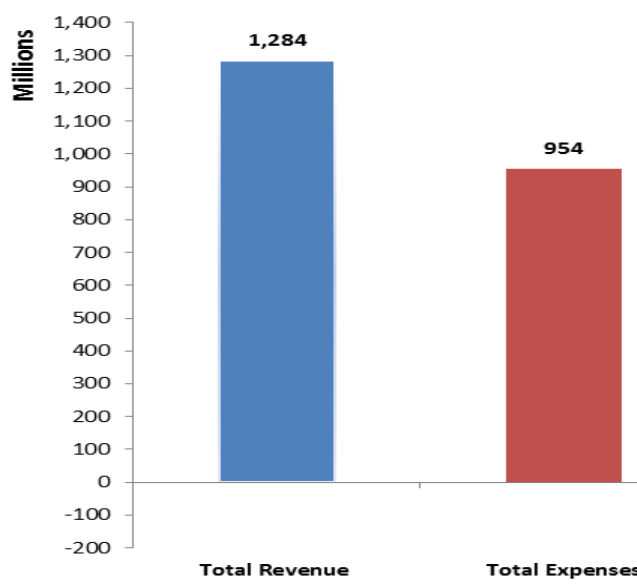

Shown in Table (3) \& Figure (7) that the total surplus of current activity in the Al-Ahly Club during the period from 2004 to 2012 amounted to 330.2 million pounds as cash surplus values ranged between (- 6.4 million pounds), (9.66 million pounds). Revenue and expenditure account after deducting depreciation and provisions for the same period showed a deficit of 36.4 million pounds as financial values of surplus after depreciation ranged from 39.7 million pounds deficit in 2012 to the surplus of 21.5 million pounds in 2006

\section{Fourth: The multiple regression equation}

To find the equation which describes the relationship between the dependent variable (surplus) and the independent variable (revenue - expenses) for Al Ahly Club over 9 years, dependent and independent variables entered using the Step Wise way to the statistical program SPSS, which only show independent variables and influential moral in the dependent variable, in the regression equation multiple linear which are shown in table (6) In order to arrive to that equation predictive necessary to determine the correlation coefficients between the independent variables with each other as well as the correlation coefficients between the independent variables and the dependent variable, which will be seen from the table (4) (5)

Table (4) shows the existence of extrusive correlation between administrative expenses and miscellaneous income, units revenues, income from Al-Ahram contract, where the value of the correlation coefficient $=0.723$ $0.898-0.724$, respectively. Values greater than the value (R) Tabulated at the 0.05 level is 0.549 . Also there is e correlation at the 0.05 level among social activity expenses and revenues of both memberships and annual fees. Social activity, where the value of the correlation coefficient $=0.638-0.890$, respectively, which is .549 greater than the value of $(\mathrm{R})$ Tabulated at the 0.05 level

Table (4) correlation matrix between revenues and expenses from 2004 to 2012

\begin{tabular}{|c|c|c|c|c|c|c|c|c|}
\hline No & Revenues & administrative & Unit & Social activity & Games & $\begin{array}{c}\text { Ahly } \\
\text { magazine }\end{array}$ & Centenary & Depreciation \\
\hline 1 & $\begin{array}{c}\text { Memeberships \& } \\
\text { annual fees }\end{array}$ & 0.176 & -0.120 & $0.638 *$ & 0.185 & 0.371 & 0.312 & -0.047 \\
\hline 2 & Miscellaneous income & $0.723^{*}$ & -0.075 & 0.244 & $0.680 *$ & 0.147 & -0.239 & 0.850 \\
\hline 3 & Units revenues & $0.898^{*}$ & 0.421 & 0.430 & $0.768 *$ & 0.489 & -0.352 & 0.473 \\
\hline 4 & $\begin{array}{l}\text { Social activity } \\
\text { revenues }\end{array}$ & 0.437 & -0.100 & $0.890 *$ & $0.563 *$ & $0.663 *$ & 0.449 & 0.141 \\
\hline 5 & Games revenues & 0.391 & -0.344 & 0.286 & $0.668 *$ & 0.169 & 0.294 & 0.593 \\
\hline 6 & $\begin{array}{c}\text { Ahly magazine } \\
\text { revenues }\end{array}$ & -0.087 & -0.052 & 0.525 & 0.037 & 0.506 & 0.510 & -0.515 \\
\hline 7 & $\begin{array}{l}\text { Al-Ahram contract } \\
\text { revenue }\end{array}$ & $0.724^{*}$ & 0.089 & 0.128 & $0.675^{*}$ & 0.142 & -0.373 & $0.663^{*}$ \\
\hline 8 & Revenue percentage & -0.105 & -0.278 & 0.294 & 0.086 & 0.191 & $0.999 *$ & -0.066 \\
\hline
\end{tabular}




\section{(R) Tabulated at the $0.05=0.549$}

As well as there is a clear significance correlation at the 0.05 level between athletic expenses and miscellaneous income, revenue units, social activity revenues, revenue athletic, Al-Ahram contract revenue as the value of the correlation coefficient $=0.680-0.768-0.563-0.668$ 0.675 , respectively, which is .549 greater than the value (R) Tabulated at the 0.05 level is

Also an evidence of the existence of a correlation of significance at the 0.05 level between AlAhly Magazine expenses and revenues of social activity where the value of the correlation coefficient $=0.663$ which is greater than the value (R) Tabulated at the level of 0.05 is .549. With respect to the expenditure of a percentage, it was clear there is a significant correlation at the level of 0.05 between expenses and revenue percentage where the value of the correlation coefficient $=0.999$ which is .549 greater than the value $(\mathrm{R})$ Tabulated at the level of 0.05
Table (5) shows the existence of a negative correlation between miscellaneous income, units revenues, Al-Ahram contract revenue and surplus, where the value of the correlation coefficient $=-0.608,-0.587,-0.652$, respectively, which are values greater than the value $(\mathrm{R})$ Tabulated at the 0.05 level, a .549

the existence of a negative correlation between administrative expenses, athletics and surplus expenses where the value of the correlation coefficient $=-0.613$, 0.665 , respectively, which are values greater than the value (R) Tabulated at the level of 0.05 , a .549 .also there is a proportional correlation between social activity expenses and net profit as the value of the correlation coefficient $=0.665$ which is greater than the value $(\mathrm{R})$ Tabulated at the 0.05 level, a .549

Table (5) correlation matrix between the independent variables and the dependent variable (surplus) for the period from 2004 to 2012

\begin{tabular}{|c|c|c|c|}
\hline No & \multicolumn{2}{|c|}{ Independent variables } & Dependent variable (surplus) \\
\hline 1 & \multirow{8}{*}{ Revenues } & Memeberships \& annual fees & 0.030 \\
\hline 2 & & Miscellaneous income & $-0.608 *$ \\
\hline 3 & & Units revenues & $-0.587 *$ \\
\hline 4 & & Social activity revenues & 0.181 \\
\hline 5 & & Games revenues & 0.122 \\
\hline 6 & & Ahly magazine revenues & 0.478 \\
\hline 7 & & Al-Ahram contract revenue & $-0.652 *$ \\
\hline 8 & & & 0.243 \\
\hline 9 & \multirow{6}{*}{ Expenses } & administrative expenses & $-0.613 *$ \\
\hline 10 & & Units expenses & 0.079 \\
\hline 11 & & Social activity expenses & $0.665^{*}$ \\
\hline 12 & & Games expenses & $-0.591 *$ \\
\hline 13 & & Ahly magazine expenses & 0.122 \\
\hline 14 & & expenses_percentage & 0.252 \\
\hline 15 & Depreciation & Depreciation & -0.468 \\
\hline
\end{tabular}

\section{(R) Tabulated at the $0.05=0.549$}

Table (6) shows that the multi-correlation coefficient $\left(\mathrm{R}^{2}\right)$ $=1.00$ in all the independent variables for the dependent variable (surplus) noting that the value of $\mathrm{R}^{2}$ ranging from $\mathrm{R}^{2} \geq 1 \leq 0$. The following will review predictive model resulting from the multiple regression equation 
Table (6) multiple regression analysis of the independent variables. $\mathrm{n}=15$

\begin{tabular}{|c|c|c|c|c|c|c|}
\hline \multirow{2}{*}{ No } & \multirow{2}{*}{ Model } & \multirow{2}{*}{ Cod } & \multicolumn{2}{|c|}{ Unstanderized coefficients } & \multirow{2}{*}{$\begin{array}{c}\text { Standerized } \\
\text { coefficient }\end{array}$} & \multirow{2}{*}{$\mathrm{R}^{2}$} \\
\cline { 4 - 6 } & & & $\mathrm{B}$ & Std. Erore & \\
\cline { 2 - 6 } & Constant & $\mathrm{A}$ & 38791568.50 & 0.00 & Beta & \\
\hline 1 & Memeberships \& annual fees & $\mathrm{b}_{1}$ & -2.10 & 0.00 & -0.64 & 1.00 \\
\hline 2 & Miscellaneous income & $\mathrm{b}_{2}$ & -3.46 & 0.00 & -0.73 & 1.00 \\
\hline 3 & Games revenues & $\mathrm{b}_{3}$ & 2.05 & 0.00 & 0.87 & 1.00 \\
\hline 4 & Ahly magazine revenues & $\mathrm{b}_{4}$ & -8.26 & 0.00 & -0.21 & 1.00 \\
\hline 5 & Al-Ahram contract revenue & $\mathrm{b}_{5}$ & -3.85 & 0.00 & -1.12 & 1.00 \\
\hline 6 & Centenary revenue & $\mathrm{b}_{6}$ & -3.03 & 0.00 & -0.53 & 1.00 \\
\hline 7 & Social activity expenses & $\mathrm{b}_{7}$ & 22.27 & 0.00 & 0.81 & 1.00 \\
\hline
\end{tabular}

\section{Multiple Regression Equation}

$$
\begin{array}{ll}
\mathbf{S}^{7}= & \mathbf{A}+b_{1} \times 1+b_{2} \times 2+b_{3} \times 3+b_{4} \times 4+b_{5} \times 5+b_{6} \times 6+b_{7} \times 7 \\
\text { - } & \mathbf{S}=\text { Surplus } \\
\text { - } & \mathbf{b}_{\mathbf{1}}=\text { Memeberships and annual fees } \\
\text { - } & \mathbf{b}_{\mathbf{2}}=\text { Miscellaneous income } \\
\text { - } & \mathbf{b}_{\mathbf{3}}=\text { Games revenues } \\
\text { - } & \mathbf{b}_{4}=\text { Ahly magazine revenues } \\
\text { - } & \mathbf{b}_{\mathbf{5}}=\text { Al-Ahram contract revenue } \\
\text { - } & \mathbf{b}_{\mathbf{6}}=\text { Centenary revenue } \\
\text { - } & \mathbf{b}_{7}=\text { Social activity expenses }
\end{array}
$$

\section{Discussion}

results obtained from Table(1) \& Figure (1)(2)(3) show that in the period from June 30, 2007 until June 30, 2008 Al-Ahly achieved revenues of 169.1 million pounds, with an increase of $3.7 \%$ from the previous year, which represented 47.4 million pounds

The research attributes the increase in the values of the financial analysis for this period to a windfall of centenary celebration of the club.the monetary amouts which were due and collected from the sponsors reached 25.9 million, 23.1 million pounds of the amount in June 30, 2007, and 2.8 million the June 30, 2008, also the increase in revenue to increase in athletics revenue of 14.3 million pounds compared to previous year. It represented in both legs of Barcelona and Benfica revenues, as well as the world's Handball Championship which was held on the centenary celebration .in addition to the 6.1 million pounds increase in the Al-Ahly club revenues from memberships and annual fees

The results of financial analysis show that in 2009 the club suffered a marked decline in memberships and annual fees revenue amounted 34.5 million pounds from the previous year. this had a direct impact on the total revenues of the club this year by about $0.5 \%$ compared to the previous year, indicating a defeicit in the collection of memberships fees and annual subscriptions by the club as well as the stoppage of accepting new memberships despite the presence of another branch of the club in Nasr.It is worth mentioning that the rates of decline in club revenue from subscriptions and annual fees have increased in 2011, reaching 20 million pounds compared to 2010 which requires management of the club to Find the reasons for this decline as one of the main resources of financial for Al-Ahli club on over 9 years where revenues achieved amounted to 424.8 million pounds, $33 \%$ of the total revenue. 
Results of financial analysis also show that in 2010 the club failed in maintaining the same achieved revenue in 2009, which was the highest revenue over 9 years. The noticeable decrease amounted 1.8\% from the175.9 million pounds of previous year, and estimated to be 23.7 million pounds. Research attributes this decline to significant drop in athletic revenues totaled 36.6 million pounds compared to the previous year

The club entered into a contract with Al Ahram Advertising Agency on October 23, 2008 for a period of three seasons till the end of 2010/2011 season. This contract earned a revenue 95.3 million pounds contributed $7 \%$ of the total club's revenues over 9 years. The contrct authorized Al-Ahram to put their clients' ads in all the stadium areas, the club and the exploitation of uniforms club teams as well as the right to exploit the press conferences, the establishment of recreational programs, any other advertising activity and the right of the Agency to organize and establish an annual camp for the first team Football Club subject to the approval of the coatching staff in a manner consistent with the terms of contract

The results obtained from the Table (2) and Figures (4) (5) (6) show that Total expenses over 9 years amounted to 953.9 million pounds. Athletics expenses are the highest during this period, reaching 568.3 million pounds, 59\% of the total expenses. The research justifies that to the increase in requirements training process from salaries and bonuses for coaches and players, and high contracts for the professionalisms, to the cost of internal and external team athletic camps. The above mentioned urge the rationalization of expenditure in those items, especially the players and coaches contracts. Also the need of new ways to market players and intellectual property rights of the club with regard to the rights of television broadcasting, athletic sponsorship, the club's sporting events ... etc, in order to provide the financing needs for athletic

Administrative expenses also contributed $30 \%$ of total expenses during the 9 years, due to the large expenditure represented in salaries and bonuses, general expenses, water, lighting, maintenance and repairs, printed membership cards, publications and tools written, the maintenance of playgrounds, Computer expenses, and Nasr City Library expenses which requires rationalization of administrative expensed within the club

The results obtained from the table (3) and Figure (7) of the financial values of cash surplus or deficit after depreciation depreciation for 9 years that there is confusion in the financial policy of the Al-Ahli Club and especially in the last three the years 2010, 2011, and 2012. Al-Ahly incurred the lowest surplus in the income and expenditure account after deducting depreciation and provisions to record a deficit of 13.2, 29.2, 39.7 LE respectively

In $2010 \mathrm{Al}$-Ahly attained revenues of 152.2 million pounds, the highest revenue over the 9 -year. The cash surplus of 44.9 million pounds turned to be a deficit of 13.2 million pounds after deducting depreciation of 58.2 million. The research explains the deficit to the worth of depreciation which was deducted from the cash surplus, considered to be the second largest depreciated over 9 years and with a record of 96.1 in 2011 pounds, a very attic ratio. this requires the club to prepare the necessary pilot studies to determine the expected value of the fixed assets as well attempt to modify the rates of depreciation in fixed assets, which used the accounting policy of the club over 9 years where the depreciation of fixed assets, according to the straight-line method based on the estimated productive life of each asset according to the following rates

\section{$\underline{\text { Asset }}$}

- Buildings and facilities construction

- Machinery and equipment

- Furniture and stationary

- Tools and equipment

- Cars

- Computer

\begin{tabular}{c} 
Depreciation rate \\
\hline $5 \%$ \\
$10 \%$ \\
$10 \%$ \\
$10 \%$ \\
$20 \%$ \\
$25 \% .(2: 64)$
\end{tabular}

In 2011, the surplus from current activity during the period from $1 / 7 / 2010$ to 30/6/2011 amounted to be 66.9 million pounds compared to 45 million pounds in the same period of the previous year, with an increase of 21.9 million pounds, and equivillant to $49 \%$. However revenue and expenditure account after deducting depreciation and provisions for the period from 1/7/2010 to 30/6/2011 recorded a deficit of 29.2 million pounds, for obvious reasons cited by the auditor's report on the financial 
statements of the Al-Ahli Club for the year ended June 30, 2011, namely:-

- $\quad$ Increase in Provision for possible claims by 17.2 million pounds to face taxes and seizue on the by the Cairo governorate for leasing the land the club at Al-Jezzerra district

- Increased depreciation of contacts of football players and the other sports by 21.7 million pounds in 2010/2011 budget compared to the previous year.

The auditor's report included the paragraph for guidance and attention of their content that responded to the club claim of 16089019 LE from Cairo governorate to quickly pay the value of leasing the club land at AlJezzerra district, and as a result of payment delays in the prescribed time limit, Cairo governorate seizured the club's bank account until the repayment of the due rental value which required the formation of a provision of 2700000 LE. (2:64)

In 2012 financial performance of the Al-Ahli Club slowdowned as the club's expenditures exceeded its revenues resulting in a deficit of 6.4 million pounds and by subtracting the value of annual depreciation which is 33.2 million pounds, there is a deficit of 39.7 million pounds. In this regard, the researchers believe that the revenue to expenditutres relationship is built on three possibilities in order to achieve a surplus, and these possibilities are:-

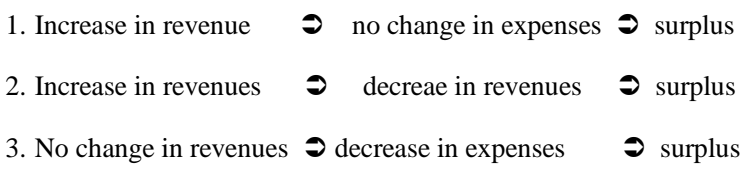

As evidenced by the results of tables (4) (5) and (6) of the correlation matrix between income, expenses, surplus, as well as analysis of multiple regression and there is a significant at 0.05 . these correlations varied between exponential correlation also multiple regression analysis showed that independent variables (revenues and expenses) that the most influential variables on the dependent variable (surplus) over 9 years are memerships and annual fees - Miscellaneous income - Games revenues - Ahly magazine revenues - Ahram contract revenue revenue of centenary celebration - social activity depreciation expenses. The explanation is that $100 \%$ of the total deviations in values of variable of surplus interpreted by the linear relationship that all the important variables were added to the model as it is the closer the value of the multiple correlation coefficient (R2) of $100 \%$ whenever this indicates that the quality of the model which is actually seen through the earlier discussionand therefore it is possible to say that this quantitative model is valid.

This is agreed with the aim of financial forecasting of allowing the opportunity to learn about the future financial needs and prepare them in advance also providing an opportunity to know what will be the financial postion and profitability in the future, and taking corrective action if necessary, given that statistical data of revenue for the past several years and each item of the budget that impact on income in those years. The multiple regression analysis is considered to be a tool to forcasting the financial needs. This method doesn't assume that there is fixed relationship between the size of the income and the size of the investment in assets as it works to forecasting the financial needs in the short term and long term, both in addition to the possibility of its use by small enterprises that suffer from volatility in their revenues.(16:127-135)

The financial analysis has a great role in the decisionmaking which mainly aimed at the health of the financial situation that makes the institution reassuring and able to implement its strategy, moreover it ensures the safety of the investment decisions. So the role its role in rational decision-making requires the provision information as well as the use of modern techniques and effective methods of functioning, in addition determining financial resources to identify the strengths to maximize them and weaknesses to minimize them. All of these cants are done without the analysis of information relating to and affecting the financial records of the foundation. (4:20) $(25: 209-235)(13: 121)$

The research suggests that there is a need to find new resources of self-financing for clubs and how to activate the resources of current and different self-financing resources based on both Khalid Ibrahim Abdulaaty (2000), Kemal Dervis, Ashraf Abdel Moez (2000) and with the results of Mohammed Abdul Qadir study (2005) that the self-financial is all revenue generated by sports clubs by investing their facilities or premises or activities, whether earnings from annual subscriptions of members, membership fees, sale of match tickets, concerts held by clubs, marketing social services, facilities or rent revenues deposits. ( 5:15)(11:44 )(15:60)

\section{Conclusion}

In light of the results of the analysis of Al-Ahly financial statements for the period from 2004 -2012, represented in the list of the balance sheet financial analysis - the statement of profits and losses - the statement of cash flows and attached explanatory notes, the following have been concluded 
1. Relative High rates of revenue of both athletic and memberships and annual fees revenues over the period from 2004 to 2012, which amounted to 876.2 million pounds, up $67 \%$ of the total club revenues for the same period

2. There is a proportional correlation between the relativeness of revenues to expenses, a logical relationship in accordance with accounting standards

3. limited number of resources of self-financial of the Club and lack of diversity during the period from 2004 to 2012

4. large percentage of depreciation and provisions with Al-Ahly Club during the period from 2004 to 2012

5. decision makers within the Al-Ahly Club could benefit to some extent the process of creating huge financial analysis to forecasting the annual cash surplus and then determine the financial needs from resources that create excess cash over the past nine years through predictive model resulting from the multiple regression equation

\section{$S^{7}=A+b_{1} \times 1+b_{2} \times 2+b_{3} \times 3+b_{4} \times 4+b_{5} \times 5+b_{6} \times 6+b_{7} \times 7$}

- $\mathbf{S}=$ Surplus

- $\quad \mathbf{b}_{1}=$ Memeberships and annual fees

- $\quad \mathbf{b}_{2}=$ Miscellaneous income

- $\mathbf{b}_{\mathbf{3}}=$ Games revenues

- $\quad \mathbf{b}_{\mathbf{4}}=$ Ahly magazine revenues

- $\quad \mathbf{b}_{5}=$ Al-Ahram contract revenue

- $\mathbf{b}_{6}=$ Centenary revenue

- $\quad \mathbf{b}_{7}=$ Social activity expenses

\section{Recommendations}

1. Al-Ahly club should Pay attention to resources of revenue and expenses socially the most influential in the cash surplus over the past nine years namely; memberships and annual fees, miscellaneous income, athletic revenues, Ahly magazine revenues, Al-Ahram contract revenue, Centenary revenue and social activity expenses
2. Attention to the process of financial analysis because of its active role in determining the financial position for athletic bodies as well as its role in rationalizing investment decisions

3. Egyptian sports clubs boards of directors should be guided by predictive model reached by the study to forecasting financial needs in order to build other predictive models contribute to the development of self-financing resources and finding new resources of financial

4. The need to focus on accuracy of data reported in the financial statements for sports clubs and the availability of transparency in the disclosure of its contents.

5. Committee of physical education sector should include the financial analysis curriculum for students of sports administration major at faculties of Physical Education at Egyptian universities

\section{References}

\section{Arabic Reference}

1. The report of the club's board about club's budget \& draft budget for 2009/2010

2. The report of the club's board about club's budget \& draft budget for 2010/2011

3. Halima Khalil El Gergawy: The role of the financial analysis for the financial information published in the financial statements to Forecast the prices of equities, master dgree, faculty of commercial, eslamic university ,gaza, Palestine, 2008[ONLINE] Available at:http://library.iugaza.edu.ps/thesis/79582.pdf:

4. Hanfy Abdelghafar: basics of financial analysis \& feasibility study @Aldar Elgamaia, Alexandreia,Egypt, 2004

5. Khaled Abd Elatty: suggestion methods for championship marketing, master degree, faculty of physical education for men, helwan university , Cairo, 2000

6. Samer Abdelhameed: Sports institutions management : modern \& implementation theatrical, @Manshat Elmaaref, Alexandreia, Egypt, 1999

7. Sahry Jamal Abdel Nasser: The financial analysis as a tool for making decision in the petroleum enterprises in Algeria, study the case of ENSP institution (2010, 2011,2012), master degree, faculty of economic \& commercial science, Qasdy Merbah university , Elgar, 2012 [ONLINE] Available at: http://bu.univouargla.dz/master/pdf/sakhri_Djamel _eco.pdf?idmemoire $=424$ 
8. Abdelsalam Abokahf : Marketing, (CAldar Elgamaia, Alexandreia,Egypt, 2005

9. Abdullah Mohiuddin:model for norms of the markting performance evaluation in some of the Egyption clubs , master degree, faculty of physical education for men, Alexandreia university , Egypt, 2007

10. Fareda Boghazy \& et.all: efficiency of using forecasting in administration system, national meeting about using of qualitative technics in administrative decision making at Elgar economics institutions, faculty of economic science

11. Kamal darwesh \& Ashraf Abdelmoes: the national sports institutions, concepts - history development - organization , CAlasdekaa library , Cairo, 2000

12. Mohamed. A. Almaydany : finnaicail management in farms, (CAlobekan, 5 ed, 2006

13. Mohamed. H. Hegazy : decisions support in institutions, (Dar Alwafaa, Alexandreia, Egypt, 2006

14. Mohamed. S. Alhenawei \& Tarek Alshehawei: modern introduction in finnaicail management (C)Aldar Elgamaia, Alexandreia,Egypt, 2011

15. Mohamed. M. Abdelkader : marketing management model in sposts club, master degree, faculty of physical education for men, helwan university , Cairo, 2005

16. Moner.I. Hendy : financial management: modern analyzing introduction, 3ed, CAlmaktb Alarbei, Alexandreia, 1997

17. Musa ben Mansour: The Role of Financial Analysis in the rationalization of mongering between the companies decision, journal of economic science, Vol. 10 , 2010, Algeria[ONLINE] Available at:

18

http://www.univecosetif.com/revueeco/Cahiers_fic hiers/revue-10-2010/04benmansour.pdf

19. Nazeer.R.Mohamed: Financial management , investment decision, 2ed, faculty of commercial, Mansoura university , 1999

20. Nour elden Aldory \& Moaed Zenad: Financial analysis by computer, Dar wael for print \& puplsher, Juordn , Aman, 2003

\section{Foren Reference}

21. Crystal Apilad: Athletic club challenges u.s.a funding, Amazon. Com, western herald, October. 30, 2003, U.S.A.

22. Dianne Waddell, Amrik S. Sohal: Forecasting: The Key to managerial Decision Making, Management Decision, Vol. 32 No. 1, 1994, pp. 41-49

23. Erik Hofmann, Kerstin Lampe: Financial statement analysis of logistics service providers: ways of enhancing performance, International Journal of Physical distribution \& Logistics Management Vol. 43 No. 4, 2013, pp. 321-342 (C)Emerald Group Publishing Limited

24. Financial Planning, Budgeting and Forecasting in Uncertain Times information week, http://www.informationweek.com/software/inform ation-management/financial-planning-budgetingand-forecasting-in-uncertain-times/d/did/1076625, 2013

25. Foster, G., Greyser, A. and Walsh, B: The business of athletic: text and cases on strategy and management, Thompson South-Western, Mason.2006

26. Jonathan, L: Predicting returns with Financial ratios, Journal of financial Economics, (74) 209235,2004

27. Planning \& financial management financial forecasting, http://skinnyohio.org/planningandfinancial/financi alforecasting.html.

28. Sergei Vasilievich: Long-Term Financial Statements Forecasting: Reinvesting Retained Earnings, Economic Department of the Mordovian State University, Russia, 2008

29. Someswar Kesh, M.K. Raja: Development of a qualitative reasoning model for financial forecasting, Information Management \&Computer Security, Vol. 13 No. 2, 2005, pp. 167-179. CEmerald Group Publishing Limited

30. Steven Isberg, Dennis Pitta: Using financial analysis to assess brand equity, journal of Product \& Brand Management, 22/1 , 2013, pp. 65-78 (C)Emerald Group Publishing Limited 
